\title{
Pengaruh Film Sexy Killers Terhadap Penggunaan Hak Pilih Mahasiswa Pada Pemilu 2019
}

\author{
Laudry Darmawan ${ }^{1^{*}}$ \\ Program Studi Ilmu Komunikasi Universitas Muhammadiyah Sumatera Utara \\ Jalan Kapten Mukhtar Basri Medan, Indonesia \\ ${ }^{* 1}$ koresponden:Laudry@gmail.com
}

\begin{abstract}
Abstrak
Penelitian ini bertujuan untuk mengetahui seberapa besar pengaruh film dokumenter Sexy Killers terhadap hak pilih mahasis wa Fakultas Ekonomi dan Bisnis UINSU pada Pemilu Presiden tahun 2019. Penelitian ini menggunakan metode survei. Responden penelitian adalah Mahasiswa dari Fakultas Ekonomi dan Bisnis Islam Universitas Islam Negeri Sumatera Utara yang berjumlah 55 orang responden. Film dokumenter Sexy Killers tidak memberikan pengaruh yang signifikan terhadap penggunaan hak pilih mahas is wa Fakultas Ekonomi dan Bisnis Islam Universitas Is lam Negeri Sumatera pada Pemilu Presiden tahun 2019, meskipun tidak dipungkiri setelah menonton film Sexy Killers para mahas is wa menemukan keraguan dalam menentukan pilihan pas angan calon presiden dan calon wakil presiden yang akan dipilih pada Pemilu 2019. Namun pilihan tersebut sudah dipilih jauh sebelum mereka menonton film dokumenter Sexy Killers tersebut dan para Mahas is wa tersebut tetap dengan pilihan utama mereka.
\end{abstract}

Kata Kunci : Film, Sexy Killers, Youtube \& Hak Pilih.

\begin{abstract}
This study aims to determine how much influence the Sexy Killers documentary film has on the suffrage of UINSU Faculty of Economics and Business students in the 2019 Presidential Election. This study uses a survey method. The research respondents were 55 students from the Faculty of Economics and Islamic Business, North Sumatra State Islamic University. The Sexy Killers documentary did not have a significant effect on the use of the suffrage of students of the Faculty of Economics and Islamic Business at the State Islamic University of Sumatra in the 2019 Presidential Election, although it was undeniable that after watching the film Sexy Killers the students found doubt in determining the choice of the presidential and vice-presidential candidate pairs the president will be elected in the 2019 election. But that choice was chosen long before they watched the documentary film Sexy Killers and the students remained with their first choice.
\end{abstract}

Keywords: Film, Sexy Killers, Youtube \& Voting Rights.

\section{PENDAHULUAN}

Film merupakan bentuk seni kompleks dan media komunikasi unik yang pengaruhnya dapat menjangkau seluruh segmen sosial di masyarakat. Film tidak hanya media hiburan yang luar biasa, tetapi film juga dapat memberikan rasa kehadiran dan kedekatan de ngan suatu dunia yang tidak tertandingi dengan tempat lain, dunia yang tak terbayangkan. Film dapat memberikan perasaan yang intens dan melibatkan orang secara langsung dan nyata dengan dunia "di luar sana" dan didalam kehidupan orang lain. Menonton film me mbawa penonton keluar dari kehidupan mereka sehari-hari dan serasa berada di dunia berbeda. Penonton tenggelam ke dalam kehidupan karakter fiksi, pemikiran merekapun mulai mengembangkan opini bersejarah dalam film, dan terus terpikat oleh kombinasi warna, cahaya dan suara yang artistik.

Film mengikat penonton secara emosional dan memiliki kekuatan yang besar dari segi estetika. Beberapa orang mengkritik film sebagai semacam hiburan untuk pelarian diri. Tetapi ada juga yang memujinya sebagai bentuk seni imajinatif yang mengijinkan orang untuk sadar akan mimpi dan fantasi mereka. 
Film sebagai media komunikasi massa memiliki peran yang cukup penting yaitu sebagai alat ukur menyalurkan pesan-pesan kepada penontonnya. Dari banyaknya film dokumenter yang ada di indonesia yang isi cerita dari film dokumenter ini yang membahas tentang kerusakan dan keterlebitan pemerintah dalam perusakan alam demi urusan bisnis mereka, tidak memikirkan apa akibat yang akan di terima. Mereka tidak memikirkan masyarakat kecil yang ada di sekitar tambang. Mereka hanya mampu membuat janji-janji tanpa menepati janji mereka sendiri.

Sistem dan penyelenggaran pemilu hampir sela lu menjadi pusat perhatian utama karena diharahapkan dapat benar-benar mewujudkan pemerintahan demokratis. Indonesia telah melakukan pemilu sebanyak sebelas periode,dimana pemilu pertama kali dilakukan pada tahnu 1955 dan terakhir kalinya pada tahun 2014. Jatuhnya kepemimpinan presiden Soeharto adalah awal dimulainya era reformasi yang membuat mekanisme pemilu mengalami perubahan. Pemilu tahun 2004 merupakan titik balik di mana seluruh rakyat Indonesia dapat mrenggunakan hak suara secara langsung untuk memilih kandidat Presiden pilihannya. Perubahan mekanisme pemilu di Indonesia menjadi secara langsung menyebabkan munculnya kandidat-kandidat baru karena diras kini setiap orang memiliki kebebasan utuk mencalonkan diri sebagai presiden Indonesia. Hal ini pun semakin memperketat peta persaingan politik baik antara kandidat maupun partai politik yang mengusungnya. Persaingan yang ketat tersebut membuat setiap kandidat dan partai politik beelomba-lomba menarik perhatian pemilih dengan melakukan marketing politik.

Konsep marketing politik yang dilakukan oleh partai atau tokoh politik agar dapat dikenal lebih jauh oleh masyarakat dan mempengaruhi sikap masyarakat dalam menentukan pilihan politik. Beberapa faktor dapat mempengaruhi hak pilih seseorang, salah satunya pendapat sekelompok orang yang secara nyata dapat mempengaruhi prilaku seseorang. Media massa merupakan alat yang digunakan dalam penyampaian pesan dari sumber kepada masyarakat atau penerima dengan menggunakan alat komunikasi. Media massa merupakan fasilitator pegenalan secara luas kepada masyarakat mengenai berbagai hal yang menyangkut pemilu serta calon kandidat.

Banyak dari kalangan mahasiswa yang semakin mantap dengan pilihan mereka dan ada pulak yang tidak yakin dengan pilihan mereka yang sebelumnya, bahkan tidak sedikit dari masyarakat dan mahasiswa untuk tidak memilih atau yang biasa di sebut dengan golput.Dari alasan di atas peneliti akhirnya tertarik pada mahasiswa FEBI UINSU sebagai responden.

Banyak dari mahasiswa yang menggunakan media youtube untuk menonton film atau hiburan lain nya, sehingga mempermudah peneliti untuk meneliti film sexy killers yang tayang hanya di youtube dan sempat tranding di media sosial. Berdasarkan alasan diatas, peneliti tertarik untuk meneliti, bagaimana pengaruh film sexy killers terhadap hak pilih mereka di pemilu tahun 2019, dan pengetahuan mahasiswa FEBI UINSU. Peneliti ingin mengetahui seberapa besar dampak film sexy killers yang keluar pada tanggal 13 April 2019 tepat 1 hari sebelum pelaksanaan pemilu serentak di selenggarakan. Apakah film tersebut dapat mempengaruhi hak pilih pada mahasiswa atau hanya sekedar film yang biasa di kalangan mahasiswa, sehingga tidak menimbulkan efek pada mahasiswa.

Penelitian terdahulu didapatkan dari beberapa sumber yang telah dipublikasi serta relevan dengan topik penelitian peneliti, menunjukan bahwa a lasan utama mengapa orang tidak menggunakan hak pilihnya dalam pemilihan presiden 2015 di Negeria adalah psikologis mereka dan disposisi terhadap politik yang menegaskan prinsip-prinsip potensi politik dan model pilihan rasional. Hasil penelitian Hilda Coffe and Elizabeth Theiss Morse (2016:43) menunjukkan bahwa siswa memilih kandidat dengan pengalaman politik yang paling kompeten dalam 
menangani masalah ekonomi, dan kandidat dengan latar belakang pendidikan yang paling kompeten dalam menangani pelayanan manusia. Gabriela Ribes Giner dan Maria Fuentes Blasco (2013:56) mejelaskan marketing politik berpusat kepada kandidat dengan faktor terbesar yang mempengaruhi lewat media.

Dari alasan di iatas peneliti akhirnya tertarik menjadikan mahasiswa Fakultas Bisnis Islam UINSU sebagai responden, karena film ini mengangkat sebuah permasalahan di balik tambang batu bara sebagai sumber listrik negara, dan keterlibatan pemerintah yang mengelola tambang batu bara tersebut atas keterlibatan dari kedua pasangan calon presiden dan wakil presiden indonesia 2019-2024. Maka dari itu dalam film sexy killers yang di produksi oleh watcdoc ini ingin memperlihat kepada masyarakat apa yang sebenarnya terjadi pada warga sekitaran tambang batu bara yang sangat memprihatinkan. Film sexy killers yang pertama kali tayang di youtube pada tanggal 13 April 2019 satu hari sebelum pemilihan umum di Indonesia di laksanakan membuat masyrakat dan mahasiswa sangat tertarik menonton film tersebut dan mengambil kesimpulan dari film tersebut.

\section{KERANGKA TEORETIS}

\section{Media Massa}

Media massa merupakan sarana penyampaian komunikasi dan informasi yang dilakukan penyebaran komunikasi secara massal dan dapat diakses oleh masyarakat pula. Menurut Fred S. Sebert dalam bukunya Communication in Moddem Society (1948), media massa tidak mungkin memilikisemua tanggung jawab dalam penyebaran kebeneran. Media hanya mengatakan banyak tentang kebenaran sehingga publik mengetahui kejadian-kejadian atau kegiatan-kegiatan yang sedang berlangsung.

Menurut Siebert media massa adalah membuat rakyat seluruh dunia bisa memperoleh isi informasi yang memungkinkan mereka memiliki sebuah masyarakat yang damai dan produktif, dan juga yang memberikan mereka kepuasan pribadi. Menurut Harold D.Laswell dalam The Communication of Idea (1948), media massa itu berperan sebagai pengawal di lingkungan kita, yang dapat mengungkap berbagai ancaman dan peluang yang mempengaruhi nilai-nilai komunitas. Sedangkan informasi massa merupakan informasi yang diperuntukan kepada masyarakat secara massal, bukan hanya boleh dikonsumsi oleh pribadi. Dengan demikian, maka informasi massa adalah milik publik, bukan ditujukan kepada individu masing-masing.

Media massa adalah istilah yang digunakan sekitar tahun 1920-an yang me mpunyai arti sebagai jenis media yang secara khusus di desain untuk mencapai dan memberikan informasi kepada masyarakat secara luas. Salah satu para ahli juga menjelaskan bahwa media massa menjalankan fungsi sebagai untuk mempengaruhi masyarakat dalam hal sikap dan perilaku. Melalui media massa, berbagai inovasi, ide dan gagasan dapat mencapai perubahan yang baru, (Nuruddin, 2014:69).

Pendapat lain dikemukakan oleh para ahli lainnya yang menjelaskan bahwa media massa merupakan sarana yang digunakan untuk menyampaikan pesan yang erat kaitannya dengan masyarakat luas. Lebih dalam lagi media massa adalah sarana untuk menyampaikan informasi kepada masyarakat yang dilakukan oleh seorang komunikator dan menggunakan alat sebagai proses penyampaiannya, (Cangara, 2010:123). 
Vol 3No. 1, 2020, 24-37

DOI: $10.30596 /$ perseps i.v\%vi\% i.4444

\section{Jenis-Jenis Me dia Massa}

Menurut pendapat para ahli, media massa memiliki tiga model utama. Adapun jenisjenis media tersebut, antara lain sebagai berikut : (Cangara, 2010:74).

a) Media Elektronik

Media elektronik menyebarkan pesan melalui pesan suara. Kecepatan dan ketepatan waktu dalam menyebarkan pesan lebih cepat dibandingkan dengan media cetak. Pada zaman dahulu, media elektronik muncul melalui radio, seiring perkembangannya media elektronik menjadi lebih baik, yakni dengan teknologi gambar dan audio visual yang lebih baik. Yang menjadi media elektronik dalam media massa adalah radio dan televisi.

b) Media Cetak

Media cetak pertama kali terbit pada awal 1920-an. Pada awalnya media cetak digunakan sebagai bentuk doktrin kepada masyarakatmya, sehingga membawa pembaca kepada suatu tujuan tertentu. Namun sekarang media cetak digunakan untuk memberikan informasi kepa da khayalak dengan berlandaskan kepada kebebasan pers. Yang termasuk media cetak antara lain surat kabar, majalah, tabloid dan hal-hal sejenis lainnya.

c) Media internet

Media internet mulai muncul pada tahun 1997. Media internet dapat dikatakan lebih canggih dibandingkan media cetak maupun media elektronik. Hal ini dikarenakan media internet atau media online sudah menggunakan jaringan website. Yang termasuk kedalam media internet adalah media online dan media sosial.

Media massa dalam penyebarannya, mempunyai karakteristik tersendiri. Menurut para ahli, ada beberapa karakteristik media massa, antara lain sebagai berikut : (Cangara, 2010:76).

a) Komunikator terlembaga

Dalam komunikasi massa, komunikatornya bergerak dalam sebuah organisasi yang terlembaga, misalnya media tele visi, radio dan media internet.

b) Pesan bersifat umum

Dalam media massa, pesan yang disampaikan harus lah bersifat untuk masyarakat luas dan diperuntukkan kepada masyarakat luas. Kemudian proses komunikasi juga harus bersifat terbuka

c) Komunikannya heteroren

Dalam media massa, komunikasi yang disebarkan tidak hanya diperuntukkan kepada sebagian masyarakat saja. Namun harus kepada masyarakat luas tanpa mengenal dan mengetahui siapa masyarakatnya.

d) Pesan yang disampaikan satu arah

Dalam media massa, pesan yang disampaikan oleh komunikator sifatnya satu arah, artinya komunikator yang memegang peran dalam proses penyampaian informasi untuk masyarakat publik.

e) Umpan balik tertunda

Dalam media massa, dikarenakan antara komunikator dan komunikan tidak bertemu atau bertatap muka secara langsung dalam proses penyampaian informasi, maka komunikator tidak tahu secara langsung apakah umpan balik (feedback) yang terjadi terhadap komunikaan. 
Vol 3No. 1, 2020, 47-68

10.30596/persepsi.v\%vi\% i.4472

\section{Teori SOR}

Berdasarkan uraian-uraian diatas maka yang mendekati penelitian ini ada lah teori S-O-R (Stimulus-Organism-Response). Teori ini menjelaskan bahwa tingkah laku sosial dapat dimengerti mengenai suatu analisis dari stimulus yang diberikan dan dapat mempengaruhi reaksi yang spesifik dan didukung oleh hukuman maupun penghargaan sesuai dengan reaksi yang terjadi. Dalam arti lain, menurut Effendy efek yang ditimbulkan dari teori S-O-R adalah reaksi yang bersifat khusus terhadap stimulus khusus, sehingga seseorang dapat mengharapkan dan keseuaian antara pesan dan reaksi komunikasi (Effendy ,2007:254).

Teori yang dipaparkan sebelumnya, bahwa prinsip belajar yang sederhana, dimana efek merupakan reaksi terhadap stimuli tertentu. Dengan demikian, khalayak dapat mengharapkan dan memperkirakan suatu ikatan yang erat antar pesan-pesan media dan reaksi audiens. Dari hasil uraian di atas, maka proses komunikasi dalam teori S-O-R ini digambarkan sebagai berikut:

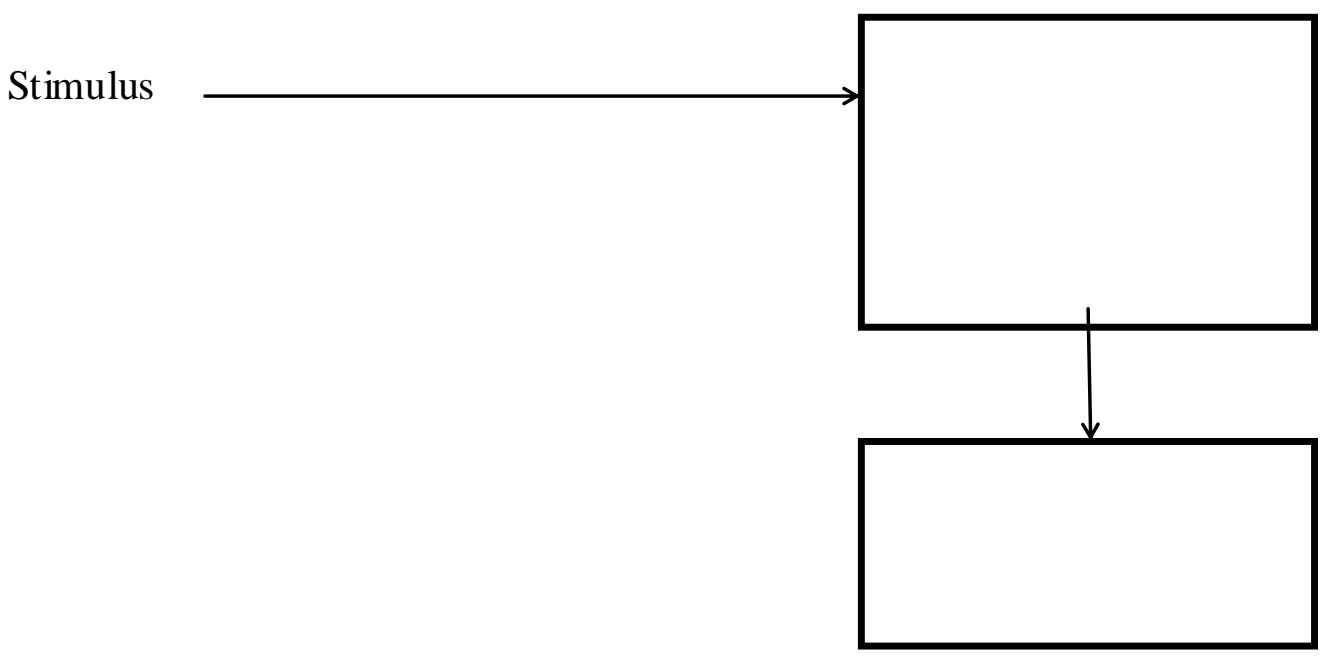

Gambar 1: Teori S-O-R (Effendy, 2007:255)

Gambar di atas menunjukan bahwa perubahan sikap bergantung pada apa yang dialami individu. Stimulus yang disampaikan ke organism mendapatkan perhatian, pengertian, penerimaan. Setelah khalayak mendapatkan organism makamunculah respons atau perubahan sikap dari khalayak yang menontonnya.

Dikaitkan denga Film Sexy Killers terhadap sikap mahasiswa FEBI UINSU, gambar diatas menunjukan bahwa:

a. Pesan(Stimulus), Stimulus atau pesan yang dimaksud adalah pesan dalam Film Sexy Killers yang ditayangkan di youtube pada tanggal 13 April 2019.

b. Komunikan (Organism), yang menjadi sasaran khalayak dalam penelitian ini adalah mahasiswa Fakultas Perbankan Syariah UINSU.

c. Efek (Respons), berupa perubahan sikap melalui tahap-tahap antara lain :

1. Pengetahuan Film komunikan bertambah setelah menonton film Sexy Killers.

2. Timbulnya perasaan suka atau ketidaksukaan terhadap salah satu calon presiden dan wakil presiden pada pemilu taun 2019.

3. Tindakan komunikan yang diw ujudkan pada pemilu tahun 2019.

Perubahan sikap dalam penelitian ini adalah perubahan sikap maupun respons mahasiswa FEBI UINSU yang memberikan pengaruh terhadap hak pilihnya pada pemilu tahun 2019 
untuk memilih salah satu dari pasang calon presiden dan wakil presiden, dan mahasiswa semakin tahu sosok dari pasangan calon presiden dan wakil presiden setelah menonton film sexy killers yang tayang di Youtube pada 13 April 2019 pada saat itu.

\section{Film}

Film merupakan alat presentasi dan distribusi dari tradisi hiburan yang lebih tua, menawarkan cerita panggung musik, drama humor, dan trik teknis bagi konsumsi populer. Film adalah bagian dari seni yang memiliki fungsi untuk menyampaikan cerita menarik dan mengandung pesan positif sehingga para penikmat film mampu mendapatkan hiburan menarik dari sebuah tayangan film baik dari musik, cerita film bahkan aktris yang memerankan tokoh dala m sebuah film (McQuai, 2011: 35).

Film juga dapat diartikan sebagai karya seni, yang diproduksi secara kreatif dan memenuhi imajinasi orang-orang yang bertujuan memperoleh estetika (keindahan) yang sempurna. Film sebagai media hiburan yang bertugas untuk menghibur setiap orang atau khalayak ramai melalui karya-karya seni yang mengandung pesan-pesan postif dan mampu mengubah sikap seseorang . film juga mampu menumbuhkan nilai seni seseorang. (Ardianto, 2004: 34).

Film sebagai komunikator dapat dibedakan melalui jenis-jenis karakteristiknya, maka film dapat dibedakan melalui jenis-jenis film antara lain:

a) Film Cerita

Film cerita merupakan jenis film yang mengandung suatu cerita yang lazim dipertunjukkan di gedung-gedung bioskop dengan bintang film tenar dan film in distribusikan sebagai barang dagangan. Cerita yang diangkat berdasarkan cerita fiktif atau berdasarkan kisah nyata yang diubah sehingga memilik cerita seni yang menarik, baik dari jalan maupun maupun dari segi gambar yang artistik. Film merupakan karya sni yang dibuat oleh sutradara yang memiliki cerita yang menarik dan merupakan karya nyata dan mimiliki nilai hiburan yang sangat tinggi dan mengandung pesan moral yang sangat baik. Biasanya film cerita berdasarkan kisah nyata sehingga banyak pesan moral dan pesan positif tergantung.

b) Film Berita

Film berita merupakan film yang mengandung banyak fakta dan peristiwa yang sangat menarik. Film berita juga harus menarik sehingga khalayak yang melihatnya tertarik dan dapat menambah pengetahuan khalayak. Film berita menganduk fakta-fakta menarik dan tidak asal-asalan dan biasanya film berita banyak memberikan informasi tentang negara, politik, dan bencana alam.

c) Film Dokumenter

Film dokumenter adalah film yang bersifat nyata dan memiliki narasumber yang jelas dan tidak asal-asalan. Film dokumenter merupakan film yang berdasarkan pengalaman pribadi seseorang dan dituangkan dalam sebuah film yang bersifat memberikan infomasi dan pengetahuan kepada khalayak yang menontonnya. Intinya film dokumenter tetap berpijak pada hal-hal senyata mungkin. Seiring dengan perjalan waktu, muncul berbagai aliran dari film dokume nter misa lnya dokudrama (docudrama). Dalam dokudrama, terjadi reduksi realita demi tujuan-tujuan estetis, agar gambar dan cerita menjadi lebih menarik. Sekalipun demikian, jarak antara kenyataan dan hasil yang terjadi lewat dokudrama biasanya tidak berbeda jauh. Dalam dokudrama, realita tetap jadi pakem pegangan.

d) Film Kartun

Film kartun adalah film yang mengandung visual gambar yang tidak nyata dan banyak mengandung editan komputer sehingga gambar yang dihasilkan tidak begitu nyata. Film kartun kebanyakan disukai oleh anak-anak yang mengandung unsur komedi dan lucu-lucu. 


\section{Pemilu}

Pemilu adalah wujud nyata demokrasi prosedural, meskipun demokrasi tidak sama dengan pemilihan umum, namun pemilihan umum merupakan salah satu aspek demokrasi yang sangat penting yang juga harus diselenggarakan secara demokratis. Oleh karena itu, lazimnya dinegara-negara yang menanamkan diri sebagai negara demokrasi mentradisikan pemilu untuk memilih pejabat-pejabat publik di bidang legis latif, dan eksekutif baik dipusat maupun daerah. Semua demokrasi modren melaksanakan pemilihan, tetapi tidak semua pemilihan adalah demokratis, karena pemilihan yang demokratis bukan sekedar lembang, tetapi pemilihan yang de mokratis harus kompetitif, berkala, inklusif(luas), dan definitif yakni menentukan kepemimpinan pemerintah. Adam Pzeworski (1998) menulis, minimal ada 2 alasan mengapa pemilu menjadi variabel sangat penting dalam suatu negara demokrasi;

a. Pemilu merupakan suatu mekanisme transfer kekuasaan politik secara damai. Pengertiannya adalah legitimasi kekuasaan seseorang atau partai politik tertentu tidak di peroleh dengan cara-cara kekerasan, tetapi karena yang bersangkutan memenangkan suara mayoritas rakyat melalui pe milu yang fair.

b. Demokrasi yang memberikan ruang kebebasan bagi individu, meniscayakan terjadinya konflik-konflik. Pemilu dalam konteks ini, hendaknya melembagakannya-khususnya berkenaan dengan merebut dan mempertahankan kekuasaan agar konflik-konflik tersebut diselesaikan dalam lembaga-le mbaga de mokrasi yang ada.

Pemilihan umum dianggap penting dalam proses kenegaraan, setidak-tidaknya "ada dua manfaat yang sekaligus sebagai tujuan atau sasaran langsung yang hendak dicapai dengan pelaksanaan pemilu, yaitu pemebentukan dan pemupukan kekuasaan yang absah (otoritas) dan mencapai tingkat keterwakilan politik (political representativeness). Arbi Sanit menyimpulkan bahwa "pemilu pada dasarnya me miliki empat fungsi yakni :

1. Pembentukan legitimasi penguasa dan pemeritah

2. Pembentukan perwakilan politik rakyat

3. Sirkulasi elite penguasa

4. Pendidikan.

Oleh karena itu pemilihan umum bertujuan untuk:

a. Memungkinkan terjadinya peralihan pemerintah secara aman dan tertib

b. Melaksanakan kedaulatan rakyat

c. Melaksanakan hak-hak asasi warga negara

\section{Sexy Killers}

Sexy killers merupakan film dokumenter hasil karya watchdoc documentary. Watchdoc documentary sendiri merupakan rumah produksi film-film dokumenter tentang indonesia. Film yang diproduksi watchdoc adalah film-film dokumenter yang kritis, dan menyodorkan beberapa fakta dari rangkaian investigasi yang dirancang oleh para kru. Melalui film sexy killers ini watchdoc mengangkat isu yang relevan dengan iklim indonesia saat ini, watcdoc menyuguhkan fakta kelam dibalik terangnya lampu-lampu kota. Melalui media visual, sexy killers memberikan perspektif lain dalam usaha pemerintah memenuhi kebutuhan listrik dikota besar, dibuka dengan cukup provokatif adegan satu pasangan yang sedang berbulan madu disebuah kamar hotel. Beralih dari gemerlapnya listrik kota ke gelapnya warna batu bara. Narator menceritakan sedikit tentang batu bara dan mengapa hal ini relevan dengan adegan sebelumnya. Batu bara sendiri merupakan sumber daya penghasil listrik.

Bertetangga dengan tambang batu bara dipinggir kota samarinda sejumlah petani berada di sebelah tambang batu bara mengalami krisis air bersih. Tambang batu bara merusak jalur air bersih mereka. Warga sekitar telah hidup berdampingan bersama lumpur beberapa tahun belakangan ini, kelangkaan air bers ih pun menyebabkan mereka banyak terserang penyakit. Selain itu adanya beberapa kasus kematian anak-anak sekitar tambang batu bara yang 
meninggal dibekas kolam batu bara yang tidak direklamasi kembali oleh pihak penambang maupun pihak pemerintah. Selain lokasi tambang batu bara, tempat konversinya menjadi aliran listrik pun turut bermasalah, pe mbangunan PLTU batang yang digadang-gadang akan menjadi PLTU terbesar se-Asia Tenggara. Pemerintah mengatakan PLTU ini dapat mengakomodasi kebutuhan listrik 1-2 juta rumah tangga, lokasi PLTU yang berada di pinggir pantai ini akan berdampak pada aktivitas nelayan sekitar PLTU Batang. Transportasi kapal tongkang yang hilir mudik mengangkut batu bara akan mengakibat pencemaran lingkungan. Penolakan pembangunan PLTU di darat akhirnya berujung kriminalisasi. Pada bulan mei tahun 2014 dua warga yang menolak menjual tanahnya untuk pembangunan PLTU akhirnya dijatuhi hukuman kurungan penjara selama 7 bulan.

Sexy killers merupakan bagian terakhir dari rangkaian dokumenter hasil ekspedisi indonesia biru. Hasil perjalanan 2 jurnalis videografer, Dandhy Dwi Laksono dan Ucok Suparta, keliling indonesia pada tahun 2015. Selama sekitar setahun, mereka menempuh perjalanan bersepeda motor dari jakarta ke bali, sumba, papua, kalimantan, la lu kembali lagi ke jawa. Dari perjalanan itu mereka menghasilkan 12 film dokumenter tentang isu sosial, ekonomi, dan lingkungan. Dua di antaranya adalah Kala Benoa, tentang gerakan bali tolak reklamasi teluk benoa dan asimetris tentang industri kelapa sawit. Bagian inti sexy killers dikerjakan selama ekspedisi biru dengan mengambil lokasi kalimantan timur. Pengembangan cerita dilakukan di beberapa daerah seperti jawa, bali, dan sulawesi dengan melibatkan videografer lain di daerah-daerah itu. Sebagaimana dokumenter khsa ekspedisi indonesia biru lainnya, sexy killers juga menghadirkan sisi lain dari pembangunan insfrastruktur yang begitu mas if pada rezim Joko Widodo-Jus uf Kalla.

Di balik banyaknya pembangun PLTU batu bara, terdapat korban-korban dari kalangan petani, nelayan, dan kelompok rentan lain. Sexy killers menunjukan para korban yang terbunuh akibat tambang batu bara itu terentang dari hulu hingga ke hilir. Dari lokasi penambangan sampai tempat batu bara itu digunakan, dilokasi penambangan kaltim, misalnya petani dari jawa dan bali yang melakukan transmigrasi pada zaman order baru kini harus berhadapan dengan industri penambangan batu bara. Mereka tergusur atau tercemar. Sebelum adanya bangunan batu bara sawah tidak rusak. Sekarang sejak berdirinya tambang batu bara rakyat kecil menjadi sengsara. Lubang-lubang bekas tambang yang ditinggalkan kini juga telah menelan korban. Pada tahun 2011-2018 sudah ada 32 orang yang mati tenggelam di bekas lubang tambang di kaltim. Secara nasional pada kurun 2014-2018 terdapat 115 orang yang meninggal.

Nelayan juga terkepung PLTU sehingga sumber kehidupan mereka terancam. Terumbu karang hancur karena tumpahan batu bara atau jangkar kapal-kapal tongkang pengangkut batu bara. Di lokasi yang berbeda, asap PLTU batu bara itu telah merenggut nyawa warga sekita PLTU batu bara, seperti di PLTU sulawesi tengah. Sexy killers menyuguhkan tangis para korban dibalik gemerlap lampu yang dinikmati warga sehari-hari. Di celukan bawang, kecamatan gerokgak, kabupaten buleleng hadirnya PLTU juga membawa sejumlah masalah besar bagi warga sekitar. Pada april 2018 PLTU celukan bawang yang beroperasi sejak tahun 2015 itu telah menimbulkan dampak di kehidupan masyarakat sekitar PLTU. Ironisnya PLTU celukan bawang sebenarnya tidak pernah masuk dalam Rencana Umum Penyediaan Tenaga Listrik (RUPTL) di bali. Menurut RUPTL Nasional, bali termasuk provinsi dengan rasio elektrifikasi tertinggi di indonesia 100 persen bersama DKI Jakarta, Jawa Barat, dan Banten.

Bandingkan dengan Nusa Tenggara Timur (NTT) 70 persen atau Papua, 65 persen. Saat ini, beban puncak kebutuhan listrik bali mencapai 855 megawat. Adapun total pasokan lis trik sudah me lebihi yaitu 1248 megawatt. Ketika pasokan listrik bali sudah berlebih dan PLTU Celukan Bawang sudah menimbulkan banyak dampak buruk bagi warga setempat.

\section{Youtube}


Vol 3No. 1, 2020, 47-68

10.30596/persepsi.v\%vi\% i.4472

Youtube adalah sebuah situs web berbagi video yang dibuat oleh tiga mantan karyawan PayPal pada februari 2005. Situs web ini memungkinkan pengguna mengunggah, menonton dan berbagi video. Perusahaan yang berkantor di pusat San Bruno, California, dan memakai teknologi Adobe Flash Video dan HTML5 untuk menampilkan berbagai macam konten video buatan, dan pengguna/kreator, termasuk klip film, kelip TV dan klip video musik. Selain itu, konten amatir seperti blog video, video or is inil pendek, dan video pendidikan juga. Youtube didirikan oleh Chad Harley, Steve Chen, dan Jawed Karim, yang sebelumnya merupakan karyawan pertama PayPal. Hurley belajar desain di Indiana University of Pensnsylvania, sementara Chen dan karim belajar ilmu komputer di University of Iilinois at UrbanaChampaign.

Youtube berawal dari perusahan teknologi rintisan yang didanai oleh investasi senilai $\$ 11,5$ juta dari Sequoia Capital antara november 2005 dan april 2006. Kantor pertama youtube berada diatas sebuah restoran Jepang dan Pizzeria di San Mateo California.

\section{Hipotes is}

Hipotes is dapat diartikan sebagai suatu jawaban yang bersifat sementara terhadap permasalahan penelitian, sampai terbukti me lalui data yang terkumpul (Arikunto, 2016:71). Ha :Ada pengaruh film sexy killers terhadap penggunaan hak pilih pada pemilu tahun 2019. Ho : Tidak ada pengaruh film sexy killers terhadap penggunaan hak pilih pada pemilu tahun 2019.

\section{METODE}

Peneliti menggunakan metode survei. Survei merupakan tipe pendekatan dalam penelitian, yang ditujukan kepada sejumlah individu atau kelompok yang jumlahnya relatif besar dengan menggunakan kuisioner dengan batasan pada pengertian survei sampel sebagai informasi dari sebagian populasi yang mewakili sebagian populasi yang ada.

Metode survei menurut Faisal (2003: 23), peneliti hedak menggambarkan karakteristik tertentu dari suatu populasi, apakah hendak berkenan dengan sikap, tingkah laku, atau aspek sosial lainnya: variabel yang ditelaah disejalankan dengan karakteristik yang menjadi fokus perhatian survei tersebut karena dimaksudkan untuk menggambarkan karakteristik tertentu dari suatu populasi, maka individu atau kelompok yang diteliti haruslah dapat mewakili populasi (representatif). Oleh karena itu, teknik sampling (cara pengambilan sampel contoh dari individu atau kelompok yang dite liti) merupakan persoalan penting pada setiap survei.

Dalam peneltian ini, peneliti ingin melihat seberapa besar pengaruh film Sexy Killers terhadap penggunaan hak pilih pada pemilu tahun 2019. Reaksi tersebut dapat berupa perhatian, perasaan, motivasi, dan diharapkan dapat menimbulkan motivasi hingga akhirnya komunikan melakukan tindakan seperti yang diharapkan komunikator ya itu mengetahui latar belakang dari ke dua pasangan calon presiden, yang ada pada film tersebut.

Untuk mempermudah operasional sehingga dapat memecahkan masalah, peneliti menggunakan variabel sebagai berikut : 
Vol 3No. 1, 2020, 24-37

DOI: $10.30596 /$ persepsi.v\%vi\% i.4444

Tabel 3.1.

Operasional Variabel

\begin{tabular}{|c|c|c|}
\hline Variabel & Dimensi & Indikator \\
\hline $\begin{array}{l}\text { Pengaruh film sexy } \\
\text { killers }\end{array}$ & Durasi & $\begin{array}{l}\text { - } \text { Berapa } \\
\text { menonton film sexy } \\
\text { killers. } \\
\text { - Berapa kali sudah } \\
\text { menonton film sexy } \\
\text { killers } \\
\text { - Di bagian mana } \\
\text { informasi yang sangat } \\
\text { menarik dalam film } \\
\text { tersebut } \\
\text { - Penggunaan hak pilih } \\
\text { mahasiswa }\end{array}$ \\
\hline $\begin{array}{l}\text { Memberi informasi } \\
\text { tentang tambang batu } \\
\text { bara menjadi sebuah } \\
\text { aliran listrik }\end{array}$ & $\begin{array}{l}\text { 1. Pengaruh } \\
\text { 2. Perhatian }\end{array}$ & $\begin{array}{l}\text { - Apa alasan menonton } \\
\text { film sexy killers. } \\
\text { - Dorongan apa untuk } \\
\text { menonton film sexy } \\
\text { killers } \\
\text { - Proses pengumpulan } \\
\text { data yang akan } \\
\text { dijadikan sebuah narasi }\end{array}$ \\
\hline
\end{tabular}

Sumber : (Singarimbun, $2005: 333)$.

Populasi penelitian ini yakni hasil pra survei dan survei mahas iswa jurusan perbankan syariah stambuk 2016 yang berjumlah 121 mahas iswa, dengan klarifikasi sebagai berikut:

a. Mahasiswa jurusan Perbankan Syariah 40 orang

b. Mahasiswa Akuntansi Syariah 40 orang

c. Mahasiswa Asuransi Syariah 41 orang 
Vol 3No. 1, 2020, 47-68

10.30596/persepsi.v\%vi\% i.4472

Dalam hal ini peneliti memerlukan sampel yang representatif dapat diartikan bahwa sampel tersebut mencerminkan semua unsur populasi yang dipilih, sehingga da pat mewakili keadaan yang sebenarnya dalam keseluruhan populasi (Sugiyono, 2016:81).

Mahasiswa Ekonomi Syariah :

$n=\frac{\mathrm{N}}{\mathrm{N} \cdot d^{2}+1}$

Keterangan :

$\mathrm{n}=$ Jumlah sampel

$\mathrm{N}=$ Jumlah Populasi

Di hitung :

$n=\frac{121}{121 \cdot 0,1^{2}+1}$

$n=\frac{121}{121.0,01+1}$

$n=\frac{121}{2,21}$

$\mathrm{n}=54,75=55$

Metode pengumpulan data adalah teknik atau cara-cara yang dapat digunakan peneliti untuk mengumpulkan data. Untuk mengumpulkan data yang dibutuhkan, maka peneliti menggunakan teknik pengumpulan data kuesioner (angket), sedangkan teknik analis is data menggunakan teknik kuantitatif karena akan ada perhitungan menggunakan angka-angka dalam penelitian serta menggunakan skala Likert. Skala Likert dikembangkan oleh Rensis Likert yang merupakan suatu series (butir soal). Responden hanya memberikan persetujuan atau ketidak setujuan terhadap butir soal tersebut (Mury Yusuf, 2014: 222):

a. Tahu diberi skor 3

b. Kurang Tahu diberi skor 2

c. Tidak Tahu diberi skor 1

Jawaban lainnya di beri skor :

a. 30-90 menit di beri skor 3

b. 10-20 menit di beri skor 2

c. $<5$ menit diberi skor 1

Jawaban lainnya diberi skor :

a. Iya diberi skor 3

b. Ragu-ragu diberi skor 2

c. Tidak diberi skor 1

Jawaban lainnya di beri skor :

a. Ragu diberi skor 3

b. Cukup Ragu diberi skor 2

c. Sangat Ragu diberi skor 1

Jawaban lainnya diberi skor :

a. Benar diberi skor 3

b. Kurang benar diberi skor 2

c. Tidak benar diberi skor 1

Jawaban lainnya diberi skor : 
Vol 3No. 1, 2020, 47-68

10.30596/persepsi.v\%vi\% i.4472

a. Setuju diberi skor 3

b. Kurang setuju diberi skor 2

c. Tidak setuju diberi skor 1

Jawaban lainnya diberi skor :

a. Iya diberi skor 3

b. Tidak Yakin diberi skor

c. Tidak diberi skor

Penjabaran data hasil survei dilakukan dalam bentuk tabel dan rumus mencari presentase (\%), antara lain sebagai berikut :

Tabel 3.2.

Contoh Tabel Dis tribusi Hasil Penelitian

\begin{tabular}{cccc}
\hline No. & Indikator Jawaban & Frekuensi/Jumlah & Presentase (\%) \\
\hline $\mathbf{1}$ & Tahu & & \\
\hline $\mathbf{2}$ & Kurang tahu & & \\
\hline & Tidak tahu & Jumlah & \\
Total Keseluruhan & $\begin{array}{c}\text { Keseluruhan } \\
\text { Responden }\end{array}$ & $100 \%$ \\
\hline
\end{tabular}

Rumus :

$\mathrm{p}(\%)=\frac{\mathrm{F} \times 100}{\mathrm{~N}}$

Keterangan :

$\mathrm{P}(\%)=$ Presentase $/$ persen

$\mathrm{F} \quad=$ Frekuensi / jumlah

$\mathrm{N}=$ Jumlah keseluruhan responden

\section{Hasil dan Pe mbahas an}

Pada Bab ini, penulis akan menyajikan data dari para responden menggunakan tabeltabel dis tribusi hasil jawaban berdasarkan angket kuisioner yang telah dilakukan oleh penulis. Yang menjadi responden penelitian adalah Fakultas Ekonomi dan Bisnis Islam Universitas Islam Negeri Sumatera Utara. Penelitian dilakukan pada hari jumat, tang gal 21 Februari 2020 pada pukul 10.00 WIB sampai dengan selesai. Adapun hasil jawaban responden penelitian, antara lain sebagai berikut :

\subsection{Hasil Jawaban Berdasarkan Karakte ris tik Res ponden}

Tabel 4.1.

Dis tribusi Hasil Jawaban Responden Berdasarkan Karakteris tik Umur

\begin{tabular}{cccc}
\hline No. & Usia & Frekuensi & Presentase (\%) \\
\hline $\mathbf{1}$ & 18-20 tahun & 37 & $67.27 \%$ \\
\hline $\mathbf{2}$ & 21-23 tahun & 18 & $32.72 \%$
\end{tabular}




\section{Jumlah Keseluruhan $\quad 55$ Responden $\quad 100 \%$}

\section{Sumber Data : Hasil Angket 2020}

Berdasarkan hasil jawaban responden penelitian berdasarkan karaktersitik umur, maka dapat diketahui sebagian besar Mahasiswa dari Fakultas Ekonomi dan Bisnis Islam Universitas Islam Negeri Sumatera Utara yang menjadi responden penelitian adalah Mahasiswa dengan umur 18-20 tahun.

Tabel 4.2.

Distribusi Hasil Jawaban Responden Berdasarkan Karakteris tik Je nis Kelamin

$\begin{array}{lll}\text { No Jenis Kelamin } & \text { Frekuensi } & \text { Presentase (\%) }\end{array}$

$1 \quad$ Laki-Laki $\quad 29 \quad 52.72 \%$

$2 \quad$ Perempuan $\quad 26 \quad 47.27 \%$

$\begin{array}{lll}\text { Jumlah Keseluruhan } & 55 \text { Responden } & 100 \%\end{array}$

\section{Sumber Data : Hasil Angket 2020}

Berdasarkan jawaban hasil penelitian dengan responden penelitian terkait karakteristik jenis kelamin, maka dapat diketahui bahwa jenis kelamin laki-laki dengan jumlah frekuensi 29 orang responden dan rata-rata presentase sebesar $52.72 \%$ dan jenis kelamin perempuan dengan jumlah frekuensi 26 orang responden dan rata-rata presentase sebesar $47.27 \%$. Dapat diketahui bahwa sebagian besar responden penelitian berjenis kelamin laki-laki. Meskipun selisih angka dari jumlah frekuensi tidak terlalu jauh dengan jumlah responden pene litian perempuan.

\subsection{Hasil Jawaban Responden Berdasarkan Distirbusi Angket Kuisioner \\ Tabel 4.3.}

Distribusi Hasil Jawaban Responden Berdasarkan Pertanyaan "Apakah Anda Tahu Film Dokumenter Sexy Killers?”

\begin{tabular}{cccc}
\hline No. & Indikator Jawaban & Frekuensi/Jumlah & Presentase (\%) \\
\hline $\mathbf{1}$ & Tahu & 42 & $76.36 \%$ \\
\hline $\mathbf{2}$ & Kurang tahu & 8 & $14.54 \%$ \\
\hline $\mathbf{3}$ & Tidak tahu & 5 & $9.09 \%$ \\
\hline & Total Keseluruhan & $\mathbf{5 5}$ Responden & $\mathbf{1 0 0 \%}$
\end{tabular}

Sumber Data : Hasil Angket 2020

Berdasarkan hasil jawaban dari responden penelitian dengan jumlah keseluruhan 55 orang responden, dapat diketahui bahwa sebagian besar responden menjawab "tahu" dengan jumlah frekuensi 42 orang responden dan rata-rata preseentase sebesar $76.36 \%$. Jawaban "kurang tahu" dengan jumlah frekuensi 8 orang responden dan rata-rata presentase sebesar $14.54 \%$. Sedangkan pada jawaban "tidak tahu" sebagian kecil dengan jumlah frekuensi 5 orang responden dan rata-rata presentase sebesar 9.09\%. Maka dapat disimpulkan bahwasannya sebagian besar dari Mahasiswa dari Fakultas Ekonomi dan B isnis Islam Universitas Islam Negeri Sumatera Utara mengetahui apa itu film Sexy Killers tersebut. Sedangkan sebagian kecil dari respon kurang mengetahui atau bahwan tidak mengetahuinya. 
Tabel 4.4.

Dis tribusi Has il Jawaban Responden Berdasarkan Pertanyaan "Apakah Sebelum Anda melihat Film Tersebut Anda Sudah Memutuskan Akan Ikut Berpartisipasi Dalam Pemilu Tahun 2019?".

\begin{tabular}{cccc}
\hline No. & Indikator Jawaban & Frekuensi/Jumlah & Presentase (\%) \\
\hline $\mathbf{1}$ & Iya & 35 & $63.63 \%$ \\
\hline $\mathbf{2}$ & Ragu-ragu & 15 & $27.27 \%$ \\
\hline $\mathbf{3}$ & Tidak & 5 & $9.09 \%$ \\
\hline & Total Keseluruhan & $\mathbf{5 5}$ Responden & $\mathbf{1 0 0 \%}$ \\
\hline
\end{tabular}

Sumber Data : Hasil Angket 2020

Berdasarkan hasil jawaban dari responden penelitian dengan jumlah keseluruhan 55 orang responden, dapat diketahui bahwa sebagian besar responden menjawab "iya" dengan jumlah frekuensi 35 orang responden dan rata-rata presentase sebesar $63.63 \%$. Kemudian jawaban "ragu-ragu" dengan jumlah frekuensi 15 orang responden dengan rata-rata presentase $27.27 \%$. Sedangkan jawaban "tidak" dengan jumlah frekuensi 5 orang responden dan ratarata presentase sebesar 9.09\%. Maka dapat disimpulkan bahwasannya sebagian besar dari Mahasiswa dari Fakultas Ekonomi dan Bisnis Is lam Universitas Islam Negeri Sumatera Utara sebelum melihat film dokumenter Sexy Killers sudah memustukan untuk ikut serta berpartisipasi da lam Pemilu 2019.

Tabel 4.5.

Distribusi Hasil Jawaban Responden Berdasarkan Pertanyaan "Apakah Anda Sebelumnya Sudah Pernah Tahu Latar Belakang Dari Kedua Pasangan Capres Dan Cawapres Yang Ikut Pemilihan Umum Tahun 2019?"

\begin{tabular}{cccc}
\hline No. & Indikator Jawaban & Frekuensi/Jumlah & Presentase (\%) \\
\hline $\mathbf{1}$ & Tahu & 27 & $49.09 \%$ \\
\hline $\mathbf{2}$ & Kurang tahu & 14 & $25.45 \%$ \\
\hline $\mathbf{3}$ & Tidak tahu & 13 & $23.63 \%$ \\
\hline & Total Keseluruhan & $\mathbf{5 5}$ Responden & $\mathbf{1 0 0 \%}$
\end{tabular}

Sumber Data : Hasil Angket 2020

Berdasarkan hasil jawaban dari responden penelitian dengan jumlah keseluruhan 55 orang responden, dapat diketahui bahwa sebagian dari responden penelitian menjawab "tahu" dengan jumlah frekuensi 27 orang responden dengan presentase sebesar 49.09\%. Kemudian jawaban "kurang tahu" dengan jumlah frekuensi 14 orang responden dengan presentase sebesar 25.45\%. Sedangkan jawaban "tidak tahu" dengan jumlah frekuensi 13 orang responden dan presentase sebesar $23.53 \%$. Maka dapat disimpulkan bahwa sebagian dari Mahasiswa dari Fakultas Ekonomi dan Bisnis Is lam Universitas Islam Negeri Sumatera Utara tahu latar belakang dari para calon Capres dan Cawapres. Sedangkan sebagian lagi kurang mengetahui dan tidak mengetahui latar belakang Capres dan Cawapres tersebut. 
Tabel 4.6.

Dis tribusi Hasil Jawaban Responden Berdasarkan Pertanyaan "Apakah Setelah melihat Film Tersebut Anda Merasa Ragu Dengan Paslon Anda?"

\begin{tabular}{cccc}
\hline No. & Indikator Jawaban & Frekuensi/Jumlah & Presentase (\%) \\
\hline $\mathbf{1}$ & Ragu & 33 & $60 \%$ \\
\hline $\mathbf{2}$ & Cukup ragu & 16 & $29.09 \%$ \\
\hline $\mathbf{3}$ & Sangat Ragu & 6 & $10.90 \%$ \\
\hline & Total Keseluruhan & $\mathbf{5 5}$ Responden & $\mathbf{1 0 0 \%}$ \\
\hline
\end{tabular}

Sumber Data : Hasil Angket 2020

Berdasarkan hasil jawaban dari responden penelitian dengan jumlah keseluruhan 55 orang responden, dapat diketahui bahwa sebagian responden menjawab "ragu" dengan jumlah frekuensi 33 orang responden dan presentase sebesar 60\%. Kemudian jawaban "cukup ragu" dengan jumlah frekuensi 16 orang responden dan presentase sebesar 29.09\%. Sedangkan jawaban "sangat ragu" dengan jumlah frekuensi 6 orang responden dan rata-rata presentase sebesar 10.90\%. Maka dapat disimpulkan bahwa Mahasiswa dari Fakultas Ekonomi dan Bisnis Islam Universitas Islam Negeri Sumatera Utara setelah melihat film Sexy Killers tersebut menjadi ragu dengan kedua paslon Pemilu Presiden 2019 tersebut. Sedangkan sebagian Mahasiswa dari Fakultas Ekonomi dan Bisnis Islam Universitas Islam Negeri Sumatera Utara bahkan menjadi cukup ragu dan sangat ragu dengan paslon Pemilu Presiden 2019 tersebut.

Tabel 4.7

Distribusi Hasil Jawaban Responden Berdasarkan Pertanyaan "Berapa Lama Anda Menonton Film Dokumenter Sexy Killers?”

\begin{tabular}{cccc}
\hline No. & Indikator Jawaban & Fre kuensi/Jumlah & Presentase (\%) \\
\hline $\mathbf{1}$ & $<5$ menit & 10 & $18.18 \%$ \\
\hline $\mathbf{2}$ & $10-20$ menit & 27 & $49.09 \%$ \\
\hline $\mathbf{3}$ & 30-90 menit & 18 & $32.72 \%$ \\
\hline & Total Keseluruhan & $\mathbf{5 5}$ Responden & $\mathbf{1 0 0 \%}$
\end{tabular}

Sumber Data : Hasil Angket 2020

Berdasarkan hasil jawaban dari responden penelitian dengan jumlah keseluruhan 55 orang responden, dapat diketahui bahwa responden yang menjawab " $<5$ menit" dengan jumlah frekuensi 10 orang responden dan rata-rata presentase sebesar $18.18 \%$. Kemudian jawaban "10-20 menit" dengan jumlah frekuensi 27 orang responden dan rata-rata presentase $49.09 \%$. Sedangkan jawaban "30-90 menit" dengan jumlah frekuensi 18 orang responden dan rata-rata presentase sebesar 32.72\%. Maka dapat disimpulkan bahwasannya Mahas iswa dari Fakultas Ekonomi dan Bisnis Islam Universitas Islam Negeri Sumatera Utara menonton film dokumenter Sexy Killers dengan durasi 10-20 menit bahkan sampai 30-90 menit. 
Tabel 4.8.

Dis tribusi Hasil Jawaban Responden Berdasarkan Pertanyaan "Apakah Film Tersebut Tidak Me mbuat Anda Ragu Dengan Pilihan Anda Terhadap Pas lon yang Anda Pilih?"

\begin{tabular}{cccc}
\hline No. & Indikator Jawaban & Frekuensi/Jumlah & Presentase (\%) \\
\hline $\mathbf{1}$ & Ragu & 29 & $52.72 \%$ \\
\hline $\mathbf{2}$ & Cukup ragu & 21 & $38.18 \%$ \\
\hline $\mathbf{3}$ & Sangat Ragu & 5 & $9.09 \%$ \\
\hline & Total Keseluruhan & $\mathbf{5 5}$ Responden & $\mathbf{1 0 0 \%}$ \\
\hline
\end{tabular}

Sumber Data : Hasil Angket 2020

Berdasarkan hasil jawaban dari responden penelitian dengan jumlah keseluruhan 55 orang responden, dapat diketahui bahwa responden yang menjawab "ragu" dengan jumlah frekuensi 29 orang responden dan rata-rata presentase sebesar $52.72 \%$. Kemudian jawaban "cukup ragu" dengan jumlah frekuensi 21 orang responden dan rata-rata presentase sebesar $38.18 \%$. Sedangkan jawaban "cukup ragu" dengan jumlah frekuensi 5 orang responden dan rata-rata frekuensi sebesar 9.09\%. Maka dapat disimpulkan bahwasannya Mahasiswa dari Fakultas Ekonomi dan B is nis Islam Universitas Is lam Negeri Sumatera Utara setelah menonton film Sexy Killers tersebut menjadi ragu dengan pilihan paslon Pemilu Presiden 2019 yang telah mereka pilih.

Tabel 4.9.

Distribusi Hasil Jawaban Responden Berdasarkan Pertanyaan "Apakah Film Sexy Killers Ini Merupakan Film Yang Memperlihatkan Keserakahan Dan Ketidakpedulian Pemerintah Kepada Mas yarakat?"

\begin{tabular}{cccc}
\hline No. & Indikator Jawaban & Frekuensi/Jumlah & Presentase (\%) \\
\hline $\mathbf{1}$ & Setuju & 39 & $70.90 \%$ \\
\hline $\mathbf{2}$ & Kurang setuju & 14 & $25.45 \%$ \\
\hline $\mathbf{3}$ & Tidak setuju & 2 & $3.63 \%$ \\
\hline & Total Keseluruhan & $\mathbf{5 5}$ Responden & $\mathbf{1 0 0 \%}$
\end{tabular}

Sumber Data : Hasil Angket 2020

Berdasarkan hasil jawaban dari responden penelitian dengan jumlah keseluruhan 55 orang responden, dapat diketahui bahwa responden yang menjawab "setuju" dengan jumlah frekuensi 39 orang responden dan rata-rata presentase sebesar $70.90 \%$. Kemudian jawaban "kurang setuju" dengan jumlah frekuensi 14 orang responden dengan rata-rata presentase sebesar 25.45\%. Sedangkan jawaban "tidak setuju" dengan jumlah frekuensi 2 orang responden dan rata-rata presentase sebesar 3.63\%. Maka dapat disimpulkan bahwasannya Mahasiswa dari Fakultas Ekonomi dan Bisnis Is lam Universitas Isla m Negeri Sumatera Utara menyimpulkan bahwa fil Sexy Killers adalah sebuah film dokumenter yang menunjukkan keserakahan dan ketidakpedulian Pemerintah terhadap masyarakat. 
Tabel 4.10

Dis tribusi Hasil Jawaban Responden Berdasarkan Pertanyaan "Apakah Didalam Film Tersebut Citra Paslon Dimata Anda Berubah?"

\begin{tabular}{cccc}
\hline No. & Indikator Jawaban & Fre kuensi/Jumlah & Presentase (\%) \\
\hline $\mathbf{1}$ & Benar & 20 & $36.36 \%$ \\
\hline $\mathbf{2}$ & Kurang benar & 27 & $49.09 \%$ \\
\hline $\mathbf{3}$ & Tidak benar & 8 & $14.54 \%$ \\
\hline & Total Keseluruhan & $\mathbf{5 5}$ Responden & $\mathbf{1 0 0 \%}$ \\
\hline
\end{tabular}

Sumber Data : Hasil Angket 2020

Berdasarkan hasil jawaban dari responden penelitian dengan jumlah keseluruhan 55 orang responden, dapat diketahui bahwa responden yang menjawab "benar" dengan jumlah 20 orang responden da rata-rata presentase sebesar 36.36\%. Kemudian jawaban "kurang benar" dengan jumlah frekuensi 27 orang responden dan rata-rata presentase sebesar $49.09 \%$. Sedangkan jawaban "tidak benar" dengan jumlah frekuensi 8 orang responden dan rata-rata presentase sebesar 14.54\%. Maka dapat disimpulkan bahwasannya Mahasiswa dari Fakultas Ekonomi dan Bis nis Islam Universitas Is lam Negeri Sumatera Utara setelah menonton film Sexy Killers tidak merubah citra paslon Pemilu Presiden 2019 di mata mereka.

Tabel 4.11

Dis tribusi Hasil Jawaban Responden Berdas arkan Pertanyaan "Apakah Menurut Anda Film Tersebut Berhubungan Dengan Citra Paslon?"

\begin{tabular}{cccc}
\hline No. & Indikator Jawaban & Fre kuensi/Jumlah & Presentase (\%) \\
\hline $\mathbf{1}$ & Iya & 42 & $76.36 \%$ \\
\hline $\mathbf{2}$ & Kurang & 10 & $18.18 \%$ \\
\hline $\mathbf{3}$ & Tidak & 3 & $5.45 \%$ \\
\hline & Total Keseluruhan & $\mathbf{5 5}$ Responden & $\mathbf{1 0 0 \%}$ \\
\hline
\end{tabular}

Sumber Data : Hasil Angket 2020

Berdasarkan hasil jawaban dari responden penelitian dengan jumlah keseluruhan 55 orang responden, dapat diketahui bahwa responden yang menjawab "iya" dengan jumlah frekuensi 42 orang narasumber dengan rata-rata presentase sebesar $76.36 \%$. Kemudian jawaban "kurang" dengan jumlah frekuensi 10 orang responden dan rata-rata presentase sebesar $18.18 \%$. Sedangkan jawaban "tidak" dengan jumlah frekuensi 3 orang responden dengan rata-rata presentase sebesar $5.45 \%$. Maka dapat disimpulkan menurut Mahasiswa dari Fakultas Ekonomi dan Bisnis Islam Universitas Islam Negeri Sumatera Utara bahwasannya film dokumenter Sexy Killers adalah sebuah film yang menceritakan tentang citra dari paslon Pemilu Presiden 2019. 
Tabel 4.12.

Dis tribusi Has il Jawaban Responden Berdasarkan Pertanyaan "Apakah Sebelum Anda Menonton Film Tersebut Anda Sudah Memutuskan Akan Memilih Pas Ion Mana Yang Akan Anda Pilih?"

\begin{tabular}{cccc}
\hline No. & Indikator Jawaban & Fre kuensi/Jumlah & Presentase (\%) \\
\hline $\mathbf{1}$ & Memilih & 36 & $65.45 \%$ \\
\hline $\mathbf{2}$ & Ragu & 11 & $20 \%$ \\
\hline $\mathbf{3}$ & Tidak memilih & 8 & $14.54 \%$ \\
\hline & Total Keseluruhan & $\mathbf{5 5}$ Responden & $\mathbf{1 0 0 \%}$ \\
\hline
\end{tabular}

Sumber Data : Hasil Angket 2020

Berdasarkan hasil jawaban dari responden penelitian dengan jumlah keseluruhan 55 orang responden, dapat diketahui bahwa responden yang menjawab "memilih" dengan jumlah frekuensi 36 orang responden dan rata-rata presentase sebesar $65.45 \%$. Kemudian jawaban "ragu" dengan jumlah frekuensi 11 orang responden dan rata-rata presentase $20 \%$. Sedangkan jawaban "tidak memilih" dengan jumlah frekuensi 8 orang responden dan rata-rata presentase sebesar $14.54 \%$. Maka dapat disimpulkan bahwasannnya sebelum menonton film dokumenter Sexy Killers, Mahasiswa dari Fakultas Ekonomi dan B isnis Is lam Universitas Islam Negeri Sumatera sudah memutuskan untuk memilih paslon Pemilu Presiden 2019.

Film merupakan alat presentasi dan distribusi dari tradisi hiburan yang lebih tua, menawarkan cerita panggung musik, drama humor, dan trik teknis bagi konsumsi populer. Film adalah bagian dari seni yang memiliki fungsi untuk menyampaikan cerita menarik dan mengandung pesan positif sehingga para penikmat film mampu mendapatkan hiburan menarik dari sebuah tayangan film baik dari musik, cerita film bahkan aktris yang memerankan tokoh dala m sebuah film (McQuail, 2011: 35).

Pada penelitian ini film yang dibahas oleh penulis adalah film dokumenter. Film dokumenter adalah film yang bersifat nyata dan memiliki narasumber yang jelas dan tidak asal-asalan. Film dokumenter merupakan film yang berdasarkan pengalaman pribadi seseorang dan dituangkan dalam sebuah film yang bersifat memberikan infomasi dan pengetahuan kepada khalayak yang menontonnya. Intinya film dokumenter tetap berpijak pada hal-hal senyata mungkin. Seiring dengan perja lan waktu, muncul berbagai aliran dari film dokume nter misa lnya dokudrama (docudrama). Dalam dokudrama, terjadi reduksi realita demi tujuan-tujuan estetis, agar gambar dan cerita menjadi lebih menarik. Sekalipun demikian, jarak antara kenyataan dan hasil yang terjadi lewat dokudrama biasanya tidak berbeda jauh. Dalam dokudrama, realita tetap jadi pakem pegangan.

Salah satu fim yang sangat menarik perhatian ketika Pemilu 2019 dan menjadi perbincangan berbagai jenis kalangan masyarakat adalah film dokumenter Sexy Killers yang dipublikasikan melalui aplikasi media sosial Youtube. Sexy killers merupakan film dokumenter hasil karya watchdoc documentary. Watchdoc documentary sendiri merupakan rumah produksi film-film dokumenter tentang indonesia. Film yang diproduksi watchdoc adalah film-film dokumenter yang kritis, dan menyodorkan beberapa fakta dari rangkaian investigasi yang dirancang oleh para kru.

Melalui film sexy killers ini watchdoc mengangkat isu yang relevan dengan iklim indonesia saat ini, watcdoc menyuguhkan fakta kelam dibalik terangnya lampu-lampu kota. Melalui media visual, sexy killers memberikan perspektif lain dalam usaha pemerintah memenuhi kebutuhan listrik dikota besar, dibuka dengan cukup provokatif adegan satu pasangan yang sedang berbulan madu disebuah kamar hotel. Beralih dari gemerlapnya lis trik 
kota ke gelapnya warna batu bara. Narator menceritakan sedikit tentang batu bara dan mengapa hal ini relevan dengan adegan sebelumnya. Batu bara sendiri merupakan sumber daya penghasil lis trik.

Bertetangga dengan tambang batu bara dipinggir kota samarinda sejumlah petani berada di sebelah tambang batu bara mengalami krisis air bersih. Tambang batu bara merusak jalur air bersih mereka. Warga sekitar telah hidup berdampingan bersama lumpur beberapa tahun belakangan ini, ke langkaan air bersih pun menyebabkan mereka banyak terserang penyakit. Selain itu adanya beberapa kasus kematian anak-anak sekitar tambang batu bara yang meninggal dibekas kolam batu bara yang tidak direklamasi kembali oleh pihak penambang maupun pihak pemerintah. Selain lokasi tambang batu bara, tempat konversinya menjadi aliran listrik pun turut bermasalah, pe mbangunan PLTU batang yang digadang-gadang akan menjadi PLTU terbesar se-Asia Tenggara. Pemerintah mengatakan PLTU ini dapat mengakomodasi kebutuhan listrik 1-2 juta rumah tangga, lokasi PLTU yang berada di pinggir pantai ini akan berdampak pada aktivitas nelayan sekitar PLTU Batang. Transportasi kapal tongkang yang hilir mudik mengangkut batu bara akan mengakibat pencemaran lingkungan. Penolakan pembangunan PLTU di darat akhirnya berujung kriminalisasi. Pada bulan mei tahun 2014 dua warga yang menolak menjual tanahnya untuk pembangunan PLTU akhirnya dijatuhi hukuman kurungan penjara selama 7 bulan.

Sexy Killers juga menceritakan seputar keterlibatan jajaran Pemerintah terkait kasuskasus yang diajabarkan dalam film dokumenter ini. Siapa-siapa saja jajaran pejabat Pemerintah yang terlibat dalam penggalian tambang batubara, pembangunan PLTU, listrik dan lain sebagainya. Ketika film ini tayang, Indonesia sedang dalam proses Pemilu Presiden 2019. Dengan calon Paslonnya di nomor 1 ada lah Ir. Joko Widodo dan Ma'ruf Amin dan nomor urut 2 Prabowo dan Sandiaga Uno. Tentunya hadirnya film Sexy Killers membentuk opini baru dimata masyarakat dimana para paslon tersebut juga hadir pada film dokumenter ini.

Peneliti melakukan riset penelitian yang bertujuan untuk mengetahui bagaimana pendapat masyarakat terkait film Sexy Killers ini dan pengaruhnya terhadap hak pilih khususnya pada Mahasiswa dari Fakultas Ekonomi dan Bisnis Islam Universitas Islam Negeri Sumatera. Dari 55 orang Mahasiswa dari Fakultas Ekonomi dan Bisnis Islam Universitas Islam Negeri Sumatera, sebagian besar mahas iswa tersebut mengetahui apa itu film dokumenter Sexy Killers. Para mahasiswa ini menonton film Sexy Killers dengan durasi waktu 10-20 menit bahkan sampai pada menit 30-90 menit. Dengan durasi tersebut, tentunya sudah memungkinkan para mahasiswa untuk memahami apa saja yang dibahas dan terjadi dalam film dokumenter tersebut.

Tekait dengan pemilihan paslon Pemilu Presiden 2019, film ini rilis di salah satu aplikasi media sosial atau yang sering disebut dengan youtube, ketika masa-masa kampanye Pemilu Presiden 2019. Namun para Mahasiswa dari Fakultas Ekonomi dan Bisnis Islam Universitas Islam Negeri Sumatera Utara sudah menentukan pilihan sebelum film ini dikeluarkan. Pilihan mereka berdasarkan kepercayaan mereka dengan paslon-paslon tersebut serta akan ikut serta dalam pemilihan Pemilu Presiden 2019. Ketika sudah menentukan pilihannya, sebagian dari Mahasiswa Fakultas Ekonomi dan Bisnis Islam Universitas Is lam Negeri Sumatera Utara, sudah mengetahui latar belakang paslon Presiden yang menjadi pilihan mereka di Pemilu 2019, sedangkan sebagian dari Mahas iswa lainnya ada yang kurang mengetahui bahkan tidak mengetahui dan memilih berdasarkan insting atau mengikuti jejak keluarganya.

Mahasiswa Fakultas Ekonomi dan B isnis Islam Universitas Islam Negeri Sumatera Utara yang sudah menonton film Sexy Killers dengan durasi waktu 20-90 menit dan memahami makna dan tujuan pembuatan film ini, mengalami keraguan akan citra dan kinerja dari paslon yang menjadi pilihan mereka di Pemilu Presiden 2019. Para Mahasiswa juga 
mengemukakan bahwa dengan adanya film dokumener Sexy Killers, dapat memberikan gambaran kepada generasi muda bagaimana politik Negeri ini beserta keserakahan dan ketidakpedulian Pemerintah kepada masyarakatnya.

Para Mahasiswa Fakultas Ekonomi dan Bisnis Islam Universitas Islam Negeri Sumatera Utara menyatakan bahwa film dokumenter Sexy Killers tidak membuat opini mereka berubah terkait citra paslon yang menjadi pilihan mereka. Benar diakui film dokumenter Sexy Killers memberikan gambaran bagaimana Pemerintah dengan masyarakat beserta dengan usaha-usaha yang dijalankan. Namun disisi lain, citra paslon masih tetap baik dimata Mahasiswa, dikarenakan banyak sisi sisi positif yang lainnya yang ditunjukkan dari kedua paslon Presiden tersebut.

Secara tidak langsung Mahasiswa Fakultas Ekonomi dan Bisnis Islam Universitas Islam Negeri Sumatera Utara juga mengatakan bahwa film Sexy Killers ini adalah film yang dibuat agar masyarakat mengetahui citra para pejabat Pemerintah terkhusus kedua capres dan cawapres itu. Namun, kembali seperti pernyataan yang telah dikemukakan sebelumnya, terlepas telah melihat film dokumenter Sexi Killers tersebut, Mahas iswa Fakultas Ekonomi dan B isnis Islam Universitas Islam Negeri Sumatera Utara tetap akan memilih paslon pilihan mereka di Pemilu 2019.

Untuk mendukung hasil penelitian tersebut, maka teori yang digunakan adalah teori S-O-R (Stimulus-Organism-Response). Teori ini menjelaskan bahwa tingkah laku sosial dapat dimengerti mengenai suatu analisis dari stimulus yang diberikan dan dapat mempengaruhi reaksi yang spesifik dan didukung oleh hukuman maupun penghargaan sesuai dengan reaksi yang terjadi. Dalam arti lain, menurut Effendy efek yang ditimbulkan dari teori S-O-R adalah reaksi yang bersifat khusus terhadap stimulus khusus, sehingga seseorang dapat mengharapkan dan keseuaian antara pesan dan reaksi komunikasi (Effendy, 2007:254).

Dari hasil penelitian yang telah dilakukan dan dikaitkan dengan film Sexy Killers terhadap sikap Mahasiswa Fakultas Ekonomi dan Bisnis Islam Universitas Islam Negeri Sumatera Utara terkait dengan hak pilih di Pemilu 2019 (Pilpres), maka dapat disimpulkan bahwa : Dari segi pesan (stimulus) yang disampaikan pada film dokumenter Sexy Killers tersebut menunjukkan bahwa pesan yang ingin disampaikan oleh penulis kepada masyarakat adalah kegiatan tambang batubara, perebutan lahan, PLTU dan hal lainnya dimana yang sangat penting disini adalah pejabat-pejabat Pemerintahan tersebut punya peran serta (andil) dalam kegiatan tersebut. Informasi yang perlu diketahui oleh masyarakat adalah dengan adanya kegiatan usaha tersebut, banyak masyarakat Indonesia yang mengalami dampak yang buruk, baik dari segi ekonomi masyarakat, individu, mental dan hak asasi manusia yang kurang baik.

Dari segi komunikan (organism), bahwa mengapa yang utama harus mengetahui perihal tersebut adalah Mahasiswa, khususnya Fakultas Ekonomi dan Bisnis Islam Universitas Is lam Negeri Sumatera Utara dikarenakan Mahasiswa adalah generasi millenial yang perlu mengetahui kondisi politik negaranya, agar nantinya dapat merubah sistem dan perkembangan baru yang lebih inovatif dan manusiawi. Ketika generasi muda melihat atau menonton film Sexy Killers ini tentunya akan timbul gejolak, rasa penasaran dan keingintahuan yang lebih mendalam tentang bagaimana penyelesaian dari kasus-kasus yang tertera dalam film tersebut. Kemudian, dengan menonton film Sexy Killers dapat membentuk perubahan sikap dan pandangan dan pilihan Mahasiswa terhadap pejabat Pemerintahan khususnya paslon capres dan cawapres pada Pemilu 2019. Pada kenyataannya, setelah melakukan penelitian, sebagian besar Mahasiswa Fakultas Ekonomi dan Bisnis Islam Universitas Is lam Negeri Sumatera Utara hanyak merasa ragu dan sangat ragu akan pilihan yang sudah ditetapkan. Namun hal itu tidak merubah pilihan mereka, dikarenakan banyak hal-hal positif yang menjadi pertimbangan para Mahasiswa untuk tetap bertahan dengan pilihannya setelah melihat film dokumenter Sexy Killers. 
Dari segi efek (respons) yang terjadi setelah Mahasiswa Fakultas Ekonomi dan Bisnis Islam Universitas Islam Negeri Sumatera Utara setelah menonton film dokumenter Sexy Killers adalah keraguan yang timbul akibat paslon yang menjadi pilihan mereka, sehingga menimbulkan sebagian kecil dari Mahasiswa tersebut berubah fikiran dan citra dari paslon capres dan cawapres yang mereka pilih diawal ketika sebelum melihat film Sexy Killers tersebut.

Berdasarkan teori SOR, maka dapat ditarik kesimpulan bahwa setelah menonton film dokumenter Sexy Killers, pesan yang disampaikan melalui film tersebut sampai dengan baik kepada Mahasiswa Fakultas Ekonomi dan Bisnis Islam Universitas Islam Negeri Sumatera Utara. Isi dari pesan tersebut menjadi informasi yang sangat bermanfaat bagi para Mahasiswa. Informasi baru yang menguak mata, pola fikir dan pandangan terhadap pejabat Pemerintahan beserta dampak-dampak yang ditimbulkan. Sexy Killers juga mengubah sebagian kecil pandangan Mahasiswa terhadap citra paslon capres dan cawapres Pemilu 2019. Namun tidak signifikan, karena sebagian besar dari Mahas iswa Fakultas Ekonomi dan Bisnis Is lam Universitas Islam Negeri Sumatera Utara tetap pada pilihan awal mereka. Hal ini dikarenakan selain citra yang berubah setelah menonton film tersebut, ada hal-hal positif yang telah dilakukan paslon capres dan cawapres yang telah dilakukan dan janji kongkrit yang dapat merubah Indonesia menja di lebih baik lagi.

\section{KESIMPULAN}

Berdasarkan hasil riset penelitian yang dilakukan, maka kesimpulan dari hasil penelitian ini sebagai berikut :

1. Film dokumenter Sexy Killers tidak memberikan pengaruh yang signifikan terhadap penggunaan hak pilih Mahasiswa Fakultas Ekonomi dan Bisnis Islam Universitas Islam Negeri Sumatera pada Pemilu tahun 2019 (Pilpres). Begitu pun tidak dipungkiri, sete lah menonton film Sexy Killers tersebut para mahasiswa menemukan keraguan dalam menentukan pilihan pasangan calon presiden dan calon wakil presiden yang akan dipilih pada Pemilu 2019. Namun pilihan tersebut sudah dipilih jauh sebelum mereka menonton film dokumenter Sexy Killers tersebut dan para Mahasiswa tersebut tetap dengan pilihan utama mereka. Maka dengan ini dapat dikatakan bahwa Ho diterima dan Ha ditolak artinya tidak ada pengaruh film sexy killers terhadap penggunaan hak pilih pada pemilu tahun 2019.

2. Film dokumenter Sexy Killers lebih memberikan edukasi dan informasi kepada Mahasiswa Fakultas Ekonomi dan B isnis Islam Universitas Islam Negeri Sumatera tentang ketidakperdulian dan keserakahan pemerintah kepada masyarakat dengan tidak memperdulikan hak asasi masyarakat Indonesia yang ditunjukkan dalam film tersebut serta mengangkat sebuah permasalahan di balik tambang batu bara sebagai sumber listrik negara, dan keterlibatan pemerintah yang menge lola tambang batu bara tersebut atas keterlibatan dari kedua pasangan calon presiden dan wakil presiden indones ia 2019-2024.

3. Film dokumenter Sexy Killers dibuat untuk menunjukkan citra dari paslon capres dan cawapres pada Pemilu Presiden 2019. Namun disisi lain, citra paslon masih tetap baik dimata Mahasiswa, dikarenakan banyak sisi sisi positif yang lainnya yang ditunjukkan dari kedua pas lon Presiden tersebut. 


\section{DAFTAR PUSTAKA}

Apriadi, Tamburaka. 2013. Literasi Media : Cerdas Bermedia Khalayak Media Massa, Jakarta. Raja Grafindo Persada.

Arikunto, Suhars imi. 2014. Prosedur Penelitian. Jakarta. PT Rineka Cipta.

Bajari, Atwar. 2015. Metode Penelitian Komunikasi: Simbiosa Rekratama Media.

Cangara, Hafied. 2014. Pengantar Komunikasi, Jakarta. Raja Grafindo Persada.

Cangara, Hafied. 2010. Pengantar Ilmu Komunikasi. Jakarta : Rajawali Press.

Effendy, Onong, Uchjana. 2011. Ilmu Komunikasi Teori dan Praktek, Bandung : PT Remaja Rosdakarya.

Effendy, Heru. 2010. Mari Membuat Film. Jakarta. Erlangga.

Maufid. Muhamad. 2010. Komunikasi dan Regulasi Penyiaran. Kencana Prenada Media Group.

Nuruddin. 2014. Pengantar Komunikasi Massa. Jakarta : Rajawali Press.

Romli, Khomsahrial. 2016. Komunikasi Massa. Jakarta : PT Grasindo

Sugiyono. 2016. Metode Penelitian Kuantitatif, Kualitatif, dan R\&D.

Suryanto. 2015. Pengantar Ilmu komunikasi. Bandung : CV Pustaka Setia

Tarumbaka, Apriadi. 2012. Agenda Setting Media Massa. Jakarta. PT Raja

Grafindo Persada.

Widjaja, H.W.A. 2010. Komunikasi dan Hubungan Masyarakat. PT Bumi Aksara.

Wiryanto. Pengantar Komunikasi. 2004. Jakarta. PT Gramedia Widiasarana Indonesia.

\section{Website}

https ://jateng.tribunnews.com/a mp/2019/04/15/s inops is-film-sexy-killers-fakta-di-balikterangnya-listrik-sege lap-batu-bara?page $=4$

http://id.m.wikipedia.org/wiki/YouTube 